\title{
Bibliotekariernas roll i skolan
}

\author{
Best Practice Article \\ Peter Kåhre* \\ Linnéus University
}

\begin{abstract}
The purpose of the study is to critically discuss the role of librarians and libraries in educational processes. The study is done as a theoretical discussion that is built up from two different angles. And none of them have earlier been discussed in connection with the concept of information literacy.

The first is about how the library as a tool has been functioning. This angle is worked out by using semiotic theories, sociological theories and learning theories. It is proposed that cultural and social processes involved in creating meaning and mediated by libraries, are dependent on structural qualities built up by the bibliographic system. Learning processes are dependent on situations and this means that library users have easier to get to the knowledge they need if they are able to use these structural capacities in libraries on their own.

The second angle comes from a cognitive science discussion about how modern computer technology extends the human minds capacity to learn. It is pointed out that this technology means that it gets even easier to use the information searching tools. It is also pointed out that the critical stance towards this Extended Mind theory is about to what extend cognitive processes need to be done in the human mind. If these processes need to be done in the mind, it is also an argument that can be directed against intermediation activities from librarians. If this it is not true and the thesis main claim is true, this means that these computer tools functions better than help from mediators because they can at least be used without the need of interfering with another person. The knowledge seeker then does not need to translate their information question to another person. When possibilities to observe knowledge is mediated through situations this also means that trial and error are better pedagogical methods than instructions.
\end{abstract}

The conclusion is that the most important strategy is to develop a good library structure and effective library tools as part of an electronic library. Librarians are needed to build and develop these libraries but it is the library and the tools in themselves that are of importance in the mediating process. These electronic libraries can be managed on a centralized level, which means small educational units can do without hiring librarians as personal mediators.

\section{Keywords:}

Librarian's role; library; education

\section{*Contact:}

Peter Kåhre*, Linnéus University, Kalmar / Växjö, Sweden

e-mail: peter.kahre@lnu.se

Nordic Journal of Information Literacy in Higher Education, 2015. C2015 Peter Kåhre 


\section{Inledning}

Hösten 2013 debatterades behovet av skolbibliotekens roll i Sverige efter att en representant för en av näringslivets tankesmedjor vid namn Gabriel Sandgren argumenterade för att kravet på bemannade skolbibliotek skulle strykas (2013). Han fick omedelbart mothugg från ett antal BoIforskare från högskolan i Borås (Dolatkhah et.al., 2013). Sandgren kanske argumenterar utifrån en intresseposition och jag känner inte några behov av att ge honom flankstöd. Däremot har jag länge förundrats över hur dåligt teoretiskt underbyggd dagens forskning kring skolbibliotekariernas roll är och det av flera skäl. Det första är att den inte riktigt tar fasta i en biblioteksvetenskaplig teori som kan visa vad biblioteksinstitutionen egentligen bidrar med $\mathrm{i}$ kunskapsprocesserna. På så sätt blir argumentationen för skolbibliotekarier mer en argumentation för behovet av en lärare i informationssökning än en bibliotekarie. Eftersom man inte förmår placera in diskussionen i hur biblioteksinstitutionen fungerar kan man heller inte se betydelsen av den tekniska utveckling som faktiskt innebär att biblioteket idag bättre än någonsin kan fungera som ett redskap utan att dess funktioner hela tiden behöver förmedlas av en bibliotekarie. Skolbiblioteksforskningen är också dålig på att sätta in den tekniska utveckling av biblioteksinstitutionen i en modern uppfattning om hur lärandeprocesser ser ut. På så sätt missar den mycket av det som talar för att det bästa är om biblioteket kan fungera som ett redskap som inte behöver förmedlas av en instruerande bibliotekarie.

Ett intressant påpekande framfördes i debatten från två personer som är inbegripna i utvecklingen av digitala skolbibliotek. Den ena, Caroline Liberg är professor i utbildningsvetenskap och hennes samarbetspartner, Eva Houltzén är chef på ett av de dataföretag som utvecklar sådana tjänster (Liberg \& Houltzén, 2013). De påpekade att blotta närvaron av en bibliotekarie är sannolikt en otillräcklig lösning på framtidens biblioteksfrågor. Det som argumentationen i denna artikel skall handla om är att vi saknar en diskussion om vad den moderna datatekniken betyder för bibliotekens sätt att fungera och vi saknar en diskussion om vilken roll bibliotekarierna skall ha för att biblioteksinstitutionen i sin helhet skall fungera bra. Eftersom frågan har att göra med bibliotekariens roll som undervisare berör frågan inte enbart skolbibliotekariens roll. Den diskussion som denna text innehåller kan därför också handla om den roll som bibliotekarier på alla typer av bibliotek har.

Dolatkhah m.fl. (2013) bygger sitt svar på att de hävdar att det finns empiriska belägg för att skolbibliotek med anställda bibliotekarier fungerar bättre än sådana där kanske bara en lärare har deltidstjänst som bibliotekarie. Det är dock ett svar som inte säger så mycket om vilken roll bibliotekarien skall ha eftersom det säkert finns ett samband mellan andra kvaliteter som storlek, mediabudget, teknisk utrustning och i hur hög grad man anställer utbildade bibliotekarier. I skolbiblioteksdiskussionen knyts oftast bibliotekariens roll till den pedagogiska funktion hon/han har i den personliga vägledningen till informationsresurserna, men vi kan inte av de empiriska resultaten se om det är just detta som skapar bibliotekens positiva funktioner eller om det är för att bibliotekarierna skapar den struktur som består av bokbestånd och tekniska redskap. Visst finns det intervjuundersökningar som säger att eleverna uppskattar de personliga insatser som bibliotekarierna gör, men det är väldigt svårt att se om det är för att de fungerar som en extra lärare/tillgänglig vuxen eller om det är för att de utför klassiska bibliotekarieuppgifter. Därför måste vi försöka komma igång men en mer grundlig diskussion av vad det är som gör att biblioteken ger ett mervärde. I ett läge när datatekniken för med sig så många aspekter som har att göra med effektivitet i informationsförmedling kan vi inte föra denna diskussion utan att på ett förutsättningslöst sätt diskutera vad tekniken kan göra. Det är det som saknas i modern biblioteksdiskussion eftersom den utgår från att det är bara genom bibliotekarien som tekniken kan fungera. I de fall diskussionen sträcker sig till att människor själva kan använda tekniken, förefaller man ändå utgå från att det först är bibliotekarier som skall instruera dem om hur de skall använda denna teknik. 


\section{Kan vi lita till empirin}

Studier av vilken kompetens människor har för att hitta information använder oftast en intervjumetodik som utgår från att människor bör använda rationella och målinriktade handlingar då de söker efter information. Genom den typen av intervjuundersökningar tycker man sig ha visat att informationsanvändare i regel uppvisar sådan osäkerhet att de behöver ha hjälp av utbildade bibliotekarier för att kunna hitta den information de behöver. Det är dock tveksamt om det är en metod som fungerar för att förstå hur människor använder de redskap som förekommer i samband med informationssökning. Det kan visst vara så att människor behöver instruktion till hur de skall använda kataloger och andra databaser men för det mesta handlar det om enkla instruktioner som kan ges via manualer eller informationsfilmer. På så sätt fångar undersökningarna inte upp något större behov av hjälp från av en informationsexpert. Det som avspeglas är att folk inte vet hur de skall få tag på det som de inte visste att de behövde, men det är också en mycket naturlig position som inte alls behöver avspegla ett problem. Vi måste alltid leta oss fram i osäkerhet men därför behöver det inte handla om att människor inte förstår hur de skall använda söktekniken. Det är också bäst om människor ges möjlighet att leta sig fram på egen hand eftersom det alltid blir ett översättningsproblem med att förklara för en bibliotekarie vad det är som efterfrågas. Därför är välutvecklade bibliografiska redskap till bättre hjälp än den man kan få från en bibliotekarie, i synnerhet som denne faktiskt aldrig kan vara en allvetande människa och speciellt inte idag då kunskapsproduktion är decentraliserad och specialiserad. Det gör att vi måste skifta fokus från bibliotekariernas handlingar till kapaciteten i de moderna datoriserade redskapen.

Om vi vill förstå skiljelinjen mellan bibliotekarie och bibliografiska redskap så är en av de viktigaste frågorna att försöka förstå hur artificiellt intelligenta program ersätter många av de handlingar bibliotekarier tidigare utförde samt hur denna funktionalitet byggs in i de datatekniska redskapen. En sådan insikt leder också fram till uppfattningen att biblioteket fungerar allra bäst om det kan finnas en direkt länk mellan detta redskap och den kognitiva förmågan hos de människor som använder biblioteken. Därför bör det kunna vara så att bibliotekariens stora uppgift handlar om att underhålla och utveckla biblioteksinstitutionen som ett redskap eller som en struktur. En sådan uppfattning för också med sig att det är detta redskap i sig som har den viktigaste rollen att spela i kognitiva eller pedagogiska kunskapsprocesser. För mig har detta inneburit att jag blivit intresserad av idéer som handlar om att den nya tekniken förändrar uppfattningen om att kunskap bara finns i människans hjärna. Tekniken innebär också att denna förmåga finns i de strukturer människan befinner sig inom. Den allra mest långtgående uppfattningen härvidlag har formulerats av kognitionsvetaren Andy Clark som den så kallade Extended mind tesen (Clark, 2003; Clark \& Chalmers, 1998), och det är med den tesen som ultimat utgångspunkt som diskussionen förs i denna text.

\section{Skolbibliotek som struktur eller skolbibliotekarier}

Idag kan skolbiblioteket vara ett elektroniskt bibliotek som erbjuder ett stort utbud av media, samt en teknisk struktur som är uppbyggd efter pedagogiska mål. Det behövs säkert utbildade bibliotekarier för att bygga upp och underhålla ett sådant bibliotek men de behöver inte finnas inom skolans väggar. Sådana redskap ger också lärarna nya möjligheter att utveckla sina pedagogiska metoder. Därför behöver vi diskutera skolbiblioteksfrågan utifrån de villkor som datatekniken skapar för de pedagogiska processerna. Tekniken ger lärarna större möjligheter att själva fungera som bibliotekarier vilket vi behöver ta i beaktande då vi argumenterar för att bibliotekarien skall utvecklas till en informationspedagog. Det kan hända att denna utveckling mot att bibliotekarien skall vara en extra lärare sågar av den gren som bibliotekarieyrket bör bygga på. Biblioteken har i alla tider försökt att fungera så pedagogiskt effektivt som möjligt och en del av det arbetet har handlat om katalogisering och annan organisering av biblioteket. Med den nya webbtekniken och dess programmering finns det oerhört många fler möjligheter för bibliotekarierna att utveckla de pedagogiska strukturerna. Webbens utveckling gör dock att vi bör inse att biblioteket inte behöver vara en fysisk plats och 
därför kan elektroniska skolbibliotek som sköts av bibliotekarier vara ett fullgott alternativ till små men bemannade skolbibliotek. Jag skall återkomma till detta genom att diskutera en pedagog som diskuterar hur en semiotisk struktur är del av en pedagogisk ambition (Stables, 2005).

Ett stort problem med åtminstone den svenska skolbiblioteksforskningen är att den är mycket normativ. Man vill gärna utgå från hur det har sett ut i tider då vi inte hade alla de datatekniska möjligheter som idag existerar. Ett exempel är att den amerikanske skolbiblioteksforskaren David Loertschers taxonomi för hur man bygger upp och skapar intresse för ett skolbibliotek är en mycket populär utgångspunkt trots att den är formulerad i början på 2000-talet och avspeglar förhållanden tidigast i början på Internetåldern (Loertscher, 2000). Därför handlar skolbiblioteksfrågan i Sverige mest om hur man skall få politiker och skolledare att satsa på skolbibliotek och skolbibliotekarier och nästan inte alls på att diskutera hur förutsättningarna har förändrats och vad de kan betyda för behovet av bemannade skolbibliotek.

\section{Informationskompetens eller informationsteknik som lyfter fram skillnader}

Om vi vill studera vilka villkor den nya tekniken ger för att utveckla den gamla klassiska bibliotekarierollen bör vi studera hur datatekniken hjälper medvetandet eller rent av ersätter medvetandet i kognitiva processer. Förutom att diskutera pedagogiska funktioner som struktur kommer jag därför att ta upp några moderna teorier om hur den nya tekniken fungerar och jag skall försöka visa hur dessa teorier gör att det mesta av den BoI-vetenskapliga pedagogikforskningens grundstenar blir utdaterade.

Informationskompetens framstår i diskussionen som en ämnesdidaktisk kompetens. Information ses som ett ämne i sig och det som man lär ut är pedagogiska metoder för att lära andra hitta denna information. Det blir dock en konstig argumentation av flera skäl. Ett är att man glömmer bort den ämneskompetens som just handlar om att bibliotekarien skall kunna veta hur man organiserar kunskap. För att kunna detta måste man först lära sig de klassiska kunskaperna inom bibliotekarieyrket. Då talar vi dock om kunskaper som inte kan jämföras med ett homogent ämne som matematik, geografi eller historia. Det handlar istället om insikter som inbegriper ämnen som klassisk informationsteori, kognitionsvetenskap, kunskapssociologi, litteraturvetenskap och datavetenskap. Det är tveksamt om man kan tala om någon enhetlig kompetens och det finns mycket små möjligheter att beskriva vad som skall ingå i en ämnesdidaktik. En bibliotekarie skaffar sig efter hand en rätt så stor erfarenhetsbaserad kunskap om hur olika saker hänger ihop men det är knappast något som enkelt kan läras ut. Det handlar om många disparata insikter och efter Internets intåg har dessa insikter blivit ännu svårare att definiera. Därför måste vi ifrågasätta begreppet informationskompetens och åtminstone inse att det inte kan vara grunden för någon ämnesdidaktisk kunskap.

En variant åtminstone för den kunskap som skall ligga bakom skolbibliotekariens ämneskompetens är den som antas behövas för det man kallar lässtimulans, vilket ofta definieras som att bibliotekarien ger lästips genom sin stora kunskap om skönlitteraturen. Bibliotekarier kan säkert mycket om sådant men värdet av den kan ifrågasättas av två skäl. Ett är att inget säger att just bibliotekarier skall känna till skönlitteratur bättre än en språklärare som säkert också genom sitt yrke har bekantat sig med skönlitteraturen. Det blir på så sätt ingen kunskap som är unik för bibliotekarieyrket. För det andra är det tveksamt om någon bibliotekarie inom sig själv kan ha en sådan bred kännedom om litteratur att man kan ge den variation i tips på litteratur som en ungdom eller vilken vuxenstuderande som helst kan behöva. Denna lässtimulerande verksamhet förefaller därför vara så fast i svunna tiders bibliotekspraktik att man inte ens tycks kunna fundera på om det inte kan vara så att det är bibliotekets struktur som skapar lässtimulans genom kataloger, bestånd och idag också bra webbteknik. Om inte bibliotekarierna har en övermänsklig insikt i all litterär mångfald är det 
troligt att de begränsas till att känna till det som alla andra känner till. Då blir risken att eleverna bara läser det som alla andra läser och i dagens läge är det lätt och relativt billigt att få tag på den litteraturen. Det kan göra att biblioteken inte ens behövs för att erbjuda den litteratur som efterfrågas. Dagens statistik över folkbibliotekens utlån ger också vid handen att det som lånas ut alltmer koncentreras till ett fătal populära titlar som redan några månader efter första publiceringsdatum går att köpa i en billig pocketupplaga på närmaste bensinstation.

Letar man efter förklaringar till att ungdomar idag läser mindre hittar man oftast sådant som hör samman med att ungdomar hittar så mycket förströelser via Internet, TV-spel och TVtittande att de inte orkar läsa mer kvalificerade böcker eftersom de är vana vid att få upplevelser i format som är lätta att konsumera. Här förefaller det vara en logisk lucka i argumentationen eftersom en bibliotekarie som högt läser en spännande berättelse för skolbarn också bör bidra till den lättillgängliga underhållsgenren. På så sätt bör detta traditionella lässtimulerande arbete leda till att man stimulerar underhållningskultur i form av lättsmälta filmer och annat.

Den strategi som kan stimulera ett behov av texter som kan användas för djupare erfarenheter bör rimligtvis gå via att man ger ungdomar ett redskap som de kan använda för sitt eget val av litteratur. Och det är här som det blir viktigt att utveckla bibliotekens strukturella egenskaper. Då handlar de pedagogiska ambitionerna inte om didaktik utan just om hur man utvecklar redskap som användarna själva kan hantera. Vi får då också in ett processperspektiv som handlar om att strukturerna får en större chans att formera om sig, beroende på från vilket perspektiv en användare möter dem. Vi ansluter då också till en definition av information som har formulerats av Gregory Bateson och som säger att information är den skillnad som gör en skillnad vid ett senare tillfälle (Bateson,1973, p. 351).

Många av de pedagoger som det brukar hänvisas till inom den bibliotekspedagogiska diskussionen kan faktiskt också användas för att stödja en strukturell syn på pedagogisk kvalitet. Vygotskys Zone of Proximal Development (ZPD) brukar inom bibliotekspedagogiken just användas för att hävda att det är bibliotekarien som skall visa vad som är möjligt. Man ser av någon anledning inte att den riktigt intressanta delen av ZPD handlar om att materiella strukturer ger möjligheter för individen att nå en ny nivå. På så sätt missar man den del av teorin som mest kan knytas till biblioteken eftersom dessa först och främst består av en materiell struktur

I den aktivitetsteori inom pedagogiken som bygger på Vygotskys idéer betonar man däremot att det är den materiella strukturen som skapar denna utvecklingszon och på så sätt ligger denna tolkning av Vygotsky betydligt närmare en strukturell syn på pedagogiska mål (se till exempel Engeström, 1987, p. 6).

En annan av de mer framträdande vygotskyinpsirerade pedagogerna, James Wersch framhåller också att det Vygotsky kallade psykologiska redskap, alltså begrepp och liknande, med tiden gavs en mer teknisk natur och innefattade sådant som olika system för att räkna, minnestekniker och algebraiska symbolsystem (Wertsch, 1985, p. 79).

\section{Meningssökande genom en reflexiv struktur}

BoI-forskningens svårighet att se att det är biblioteket som institution som skapar ett värde, och inte bibliotekarier som utför personliga handlingar gentemot kunderna, kan ha att göra med att man är så upptagen med att man bara tror att mening skapas när individer interagerar med andra individer. Det är då viktigt att påpeka att ett strukturellt perspektiv på informationsbehandling faktiskt också utgår från att meningssökande är kärnan i processerna. Dock ifrågasätter det att medvetandet med rationell bearbetning i hjärnan kan hitta meningen. Istället är det den hänvisningsrikedom som ges av strukturen som skapar mening. 
Den kände antropologen och forskaren i informationsanvändande, Lucy Suchman, beskriver väl hur begränsat det analytiska medvetandet är eftersom det ändå är beroende av erfarenhet. Därför menar hon att avsiktliga handlingar nödvändigtvis är handlingar som ges av situationer och därför är de beroende av den kontext som bildas av speciella och konkreta omständigheter. Det som vi tror är resultat av tänkande är istället beroende av den situation som bildar kontext för tankeverksamheter. Vi kommer på så sätt mycket närmare grundförutsättningar för meningsskapande och det gör också att det inte finns så stora möjligheter att skilja ett expertbeteende (till exempel inom informationssökning) från ett nybörjarbeteende (Suchman, 1987, pp. viii-ix). Hon framhåller också att moderna datasystem oftast inte kräver speciellt mycket expertkunskap från användaren eftersom vi idag använder dessa system genom att kommandon som bygger på lingvistik istället för mekanik och vi interagerar med dem genom ett naturligt språk och inte genom att trycka på knappar (Suchman, 1987, p. 11).

Om vi inser att det är informationsstrukturen som ger frihetsgraderna handlar det också om att vi bör studera hur materiella faktorer hjälper till att skapa de redskap som låter oss använda dessa strukturer. Det är här som den aktivitetspedagogiska varianten av Vygotskys pedagogiska lära blir intressant eftersom den tar sikte på hur materialitet hjälper till att utvidga den existerande kunskapen hos en individ. Yrjö Engeström, som är professor i pedagogik, hävdar i boken Learning by expanding att expansiva processer är beroende av materiella förutsättningar. Han utvecklar en kritik av strategier som syftar till att lösa problem med målrationalitet genom att hävda att den per definition inte förmår gå utöver den givna kontexten. Lärandet kan då inte utvecklas längre än vad den givna kontexten tillåter (Engeström,1987, p.4). Den är den materiella struktur som kan hjälpa oss att se längre än det givna som hjälper oss att expandera kunskapen. Det är på så sätt som vi också kan se på Vygotskys ZPD som något som kan ha en materiell struktur.

Förutom att vi kan koppla materialitet till pedagogiska processer så finns det också pedagoger som explicit diskuterar semiotikens intresse för relationer mellan olika typer av tecken och hur dessa relationer kan kopplas till ett strukturellt perspektiv. Andrew Stables visar på hur semiotiska resonemang kan användas för att utveckla en alternativ pedagogik (2005). Stables försöker övertyga oss om att det är den semiotiska strukturen som ger oss möjligheter att bli något mera än vad vi är i oss själva, vilket gör att det också här handlar om att expandera vårt medvetande. Stables kommer med en programförklaring som ligger mycket nära det som bibliotekarier brukar hävda när han säger: "att leva är att läsa och att svara på det som ges av vår omgivning" (Stables, 2005, p.1). På så sätt blir det också något som överskrider Descartes gamla skiljelinje mellan kropp och medvetande. Han menar också att teorier om erfarenhetsinlärning, som John Deweys, och teorier om Communities of Practice som hos Lave och Wenger får oss att se att denna Cartesianska distinktion inte längre håller (Stables, 2005, p.16).

Stables menar att leva betyder ett semiotiskt engagemang och det sker genom en process av repetitioner med vissa modifieringar eftersom tecknen är både givna och beroende av situationer. På så sätt förändras vårt sätt att reagera på tecken beroende på i vilka situationer vi möter dem (Stables, 2005, p. 23). Ett problem som jag upplever med skolbiblioteksforskningen är att den knyter en stor uppgift för bibliotekarierna till att vägleda eleverna om vad som är kvalitetssäkrad information. Stables angriper ett likartat tänkesätt inom pedagogiken och skolforskningen genom att diskutera skillnaden mellan att leva väl och att vara Gud. Han påpekar att den Sokratiska traditionen inte skiljer mellan dessa och gör den ultimata frågan till en moralfråga (Stables, 2005, p. 29).

Stables påpekar att vi istället skall fokusera på strukturernas förändringsprocesser och pekar på värdet av Deluzes och Guttaris begrepp Rhizome som de använder för att visa på hur 
olika veck i något vi kan kalla en struktur ger förutsättningar för att upptäcka något nytt eller till och med bestämmer vilka vägar som kan tas för att hitta nya kunskapskopplingar.

Stables tar också upp att klassrummet oftast uppfattas som en praktisk aktivitet och att lärarens kunskap är en praktisk kunskap. På så sätt blir elevernas aktivitet beroende av vad läraren gör (Stables, 2005, p. 185). Det är något som faktiskt påminner om BoI-vetenskapens uppfattning om att det är bibliotekarien som skall definiera informationssökningsprocessen. På så sätt blir möjligheterna till expansion begränsade. Stables föreslår istället att vi skall se på klassrumssituationen som en text. Han försöker visa på några exempel och hur vi med en sympatisk läsning kan se dem som exempel på när klassrummet blir en text (Stables, 2005, p. 189). Han hänvisar bland annat till ett exempel från Norman Faircloud (1995) där vi kan tolka det som att det handlar om att just texten är i centrum. Vi kan påpeka att i bibliotekssammanhang borde det explicit vara texterna och inte bibliotekarierna som sätts i centrum.

Ett argument som ofta framförs är att det är i sociala processer som kunskap förmedlas. Kunskapssociologin är full av sådana påståenden och Vygotsky brukar också användas för att hävda att pedagogiska processer måste uppfattas som sociala processer. På så sätt kan det vara svårt att hävda att en semiotisk kunskapsstruktur kan vara en förmedlare. Också här bör vi dock uppmärksamma att Vygotsky framför allt talar om hur ett begreppssystem byggs upp genom sociala processer och därefter blir det som förlänger eller förädlar de sociala processerna. Det starkaste stödet för att socialitet åtminstone inte enbart handlar om att människor interagerar med varandra hittar vi hos den sociologiska systemteorin, framför allt som den är formulerad av Niklas Luhmann. Innan vi tar upp några centrala delar av Luhmann's systemteori skall vi se på hur den amerikanske litteraturvetarprofessorn Katherine Hayles presenterar den utveckling av informationsbegreppet som skedde inom den så kallade andra ordningens cybernetik till vilken den moderna sociologiska systemteorin är starkt knuten till.

\section{Den posthumana människan och den andra ordningens cybernetik}

Hayles undersöker i sin bok How We Became Posthuman hur informationsteknologin modifierar människans syn på sin relation till maskinerna. Hon talar om människan som en cyborg, eller en posthuman varelse som är något mera än bara ett tänkande subjekt. Hon framhåller att sedan länge har människans umgänge med litteraturen gjort henne till en posthumanistisk varelse, så det är inget som bara har att göra med den moderna informationsteknologin.

En viktig del i utvecklingen av den andra ordningens cybernetik handlar om att man såg problem med informationsbegreppet. Man diskuterade hur begreppet skulle konstrueras som en teoretisk enhet och man funderade på hur mänskliga neurala strukturer kunde modelleras som ett flöde av information. Man försökte också diskutera hur informationsflöden kunde göras observerbara och verkliga genom att man konstruerade dem som artefakter. Detta gjorde att den tidiga cybernetiken låg nära den positivistiska vetenskapen och uppfattade att information stod för ett eget värde (Hayles, 1999, p. 50).

Att man började ifrågasätta denna syn hade att göra med att detta informationsbegrepp inte kunde omfatta de komplexa problem som cybernetiken försökte diskutera. Där det tidigare varit homeostasis som eftersträvades började man istället tala om villkor för reflexivitet (Hayles, 1999, p. 57).

Inom cybernetiken ledde dock så småningom den interna debatten fram till att man tog avstånd från uppfattningen om världens lagbundenhet. Då uppstod den så kallade andra ordningens cybernetik. Hayles visar att skillnaden mellan att uppfatta information som ett värde och som en kontext återkom i denna diskussion och handlade om vilken bild av människan som skulle styra designen av cybernetiska system. Diskussionen handlade om huruvida människan skulle uppfattas som en informationshanterande maskin eller som en del i en kontext (Hayles, 
1999, p. 57). Man opponerade sig mot att människan kunde vara i centrum av modellen eftersom den som studerar en människa förändrar dennes relation till maskinerna. Centrala personer kring denna utveckling som matematikern Heinz von Foerster samt antropologerna Margaret Mead och Gregory Bateson ifrågasatte att medvetandet enbart måste vara förkroppsligat i en människa. Om vi skall fånga in allt som rör medvetandet vi måste fokusera både på människan och på det system i vilket hon befinner sig (Hayles, 1999, p. 68).

Hayles diskuterar också så kallade självstyrande system som är det som skapar kopplingen mellan sociologisk systemteori och den andra ordningens cybernetik. Luhmanns systemteori bygger på att de självstyrande systemen fungerar autopoietiskt. Hayles beskriver den skillnad som finns mellan allopoietiska system och autopoietiska system. Studerar vi hur människan fungerar som ett autopoietiskt system är vi intresserade av hur individen har tillgång till de kvaliteter som ger henne möjligheter att utveckla sin individualitet. Studiet av allopoietiska system handlar däremot om att se hur de styrs av mål som är instrumentella och nedlagda i systemet utifrån (Hayles, 1999, p. 141).

Det speciella med den sociologiska systemteorin är att den tar avstånd från att sociala processer bara handlar om att människor interagerar med varandra. Istället betonar Luhmann att sociala processer handlar om kommunikation i de sociala systemen. Det är den sociala kommunikationen som kan skapa förändring medan de människor som interagerar med varandra kan endast göra det genom det som systemet tillåter. Luhmann ser information som det som genom kommunikation väljs ut av de möjligheter som exponeras ungefär som när vi använder ett bibliografiskt system för att söka efter information. Systemteorin antar dock att systemrelationerna kan förändra sig beroende på aktiviteten i systemet så det kanske mer handlar om ett system som inte bara bygger på kontrollerade begrepp utan också ett system där användning gör att företeelser som citeringsmönster och semantiska beskrivningar i fulltexter tillsammans med avancerade sökalgoritmer skapar en autonom förändring i systemet. Det skapar den selektion som gör kommunikationen möjlig (Vanderstraeten, 2000, p. 586).

Luhmann framhåller att information mellan personer bör ges i en form som yttraren och adressaten kan förstå. Men informationsprocesser kan också uppstå utan ett språk eller helt enkelt genom att inget sker. Det måste dock handla om att något utväljs och kan inte bara vara ett tecken för något annat. Dessutom måste en förändring uppstå hos mottagaren. På så sätt skapar informationen nya möjligheter för kommunikation (Vanderstraeten, 2000, p. 587). Att bara förstå det som man inom en given systemreferens känner till är inte poängen med förståelse. På så sätt är förståelse något som först kan uppstå genom att systemrelevansen förändrats. Den kritiska processen kring skapandet av ny kunskap handlar på så sätt inte om att individerna gör tankekonstruktioner i en förståelseprocess. Istället exponerar information osäkerhet. Leydesdorff framhåller att information i den luhmannska teorin alltid blir lika med osäkerhet (Leydesdorff, 1996, p. 297). Och Bateson kommer fram till att vi behöver det oklara för att ha något som vi kan skapa något nytt av. All that is not information, not redundancy, not form and not restraints - is noise, the only possible source of new patterns (Bateson, 1973, p. 386). Detta leder Bateson till att också göra den omdefinition av informationsbegreppet som vi tidigare bekantade oss med: Den skillnad som skapar en skillnad vid något senare tillfälle. Då kan vi också se på orsaken till händelser som krafter, påverkan och liknande. Det gör det möjligt att se att orsaken till dessa händelser i själva verket handlar om att skillnader har observerats (Bateson, 1973, p. 351). På så sätt blir meningssökandet viktigare än meningen och att skapa kunskap handlar på så sätt om att göra skillnaden uppenbar (Baecker, 2008, pp. 54-55). Luhmann menar också att själva definitionen av information handlar om att den har ett nyhetsvärde (Luhmann, 1971, p. 40).

Det som gör att informationsförmedling genom interaktion mellan människor fungerar dåligt är att människor aldrig helt kan förstå varandra. Sociologin använder begreppet kontingens för detta. Det som utmärker Luhmann's teori är att han också betonar den dubbla 
kontingens som framträder i interaktioner. Den innebär att en person inte bara har svårt att tolka en annan persons budskap. Den första personen har också svårt att tolka sina egna positioner i interaktionen med den andra personen. Därför går det inte att direkt förstå allt som en annan människa säger. Det som den andre människan säger kan bara öppna för vad som kan vara möjligt. Något som innebär ett budskap som den andre inte själv behöver vara medveten om att hennes uttalanden skapade möjligheter till. Dubbel kontingens förklarar därför de sociala systemens stora betydelse för kommunikationen. Eftersom människorna inte direkt kan förstå varandra måste kommunikationen gå via ett socialt system. På så sätt skapas förutsättningar för att något skall få en distinkt social mening på en världsvid dimension och samtidigt skapas förutsättningar för att kommunikationen skall leda till fortsatt differentiering inom lokala sociala system (Luhmann, 1995, p. 106).

Det öppnar för att ett socialt system måste bygga upp någon form av artefaktisk/ kulturell struktur som kommunikationen kan gå genom. Och samtidigt är det denna artefaktiska struktur som visar var skillnaden går mellan det sociala systemet och deras omvärld.

\section{Redskapens förmåga att expandera människans förmåga att lära sig något nytt}

Ovanstående visar att arenan för social kommunikation sker på en övergripande social nivå vilket betyder att förmedling på en mikronivå är mindre viktig. Men vi kan också se att mikronivån mest handlar om att individerna själva måste använda det som finns i strukturerna och att förutsättningarna för detta är viktigare än en förmedling mellan individer på en mikronivå. Vi har därför stöd för att ifrågasätta att det är bibliotekarien som tillför den pedagogiska funktion i kunskapsprocesserna som kan hjälpa bibliotekens kunder att expandera sin kunskap. Istället får vi stöd för att det alltid varit genom bibliotekens struktur, vi kan kalla det den bibliografiska strukturen, som biblioteken byggt sin position. Vi har också hävdat att den nya datatekniken ger möjligheter att utveckla denna traditionella biblioteksroll.

Vi har också redan nämnt den så kallade Extended Mind-tesen som formulerats av Andy Clark i samarbete med David Chalmers och som hävdar att datateknologin på ett avgörande sätt har förändrat människans kapacitet för att tänka och handla (Clark, 2003; Clark \& Chalmers, 1998). Vi skall börja med att diskutera programmet och se hur företrädarna för programmet argumenterar mot de som kritiserar dess grundläggande positioner. Efter att vi har gjort det skall vi ta upp en diskussion som handlar om varför vi bör omformulera ett av de ledande programmen inom BoI-vetenskapen som diskuterar hur människor söker information för att hitta mening. Det är det meningssökande paradigm som Kuhlthau har lanserat och som förefaller dominera BoI-vetenskapens uppfattning om hur informationssökningsprocesser ser ut.

I boken Being There talar Clark (1996)om hur begreppet Embodied Agents utvecklades till att bli Embedded Agents. Clark menar att kognition handlar om inbäddade relationer därför att verklig embodied intelligens måste handla om att koppla ihop sig med världen. Det är en strategi som tillåter att man kan lösa problem på ett robust och flexibelt sätt (Clark, 1996, p. 98). På så sätt kommer också hela den struktur som ett bibliotek representerar bli en del av det som en biblioteksanvändare tänker med.

Mark Rowlands (2009), som är en av de som försvarar tesen, har formulerat den som att den bygger på fyra delar. Den första handlar om ett ganska okontroversiell påstående om att världen erbjuder en från människan extern lagringsplats för den information som behövs för processer som att uppfatta, minnas, resonera och att göra erfarenheter. Det är mer kontroversiellt att hävda att åtminstone några mentala processer är hybrida på det sättet att de innehåller både interna och externa operationer. De externa processerna innebär en form av handling som manipulerar, utnyttjar och förändrar strukturen i den omgivande miljön i avsikt 
att förmedla information som är relevant för att utföra en given uppgift. Slutligen är det åtminstone några av de interna processerna som har som uppgift att ge subjektet dess förmåga att på ett korrekt sätt använda de relevanta strukturerna i omgivningen (Rowlands, 2009, p. 53). På detta sätt kommer vi långt ifrån det traditionella synsättet som brukar mena att redskap bara kan fungera som förlängning av mänskliga intentioner. Istället är det artefakter som kan förändra människornas intentioner och som kan skapa möjligheter för sociala interaktioner.

Det finns en debatt kring EM-tesen som är intressant utifrån en biblioteksdiskussion eftersom den diskussionen handlar om vilken roll redskapen har för den kognitiva förmågan och på så sätt visar den att den förmedlade handlingen inte är den centrala. Kritiken av EM handlar mest om huruvida kognition bara handlar om något som sker inom människornas medvetanden eller om det också är något som innefattar självständiga processer i olika kunskapsartefakter. Kuhlthaus meningssökande förefaller ligga nära dessa kritiker medan BoI-vetenskapliga sociokognitiv teori är mer ambivalent.

Den starkaste och mest utarbetade kritiken mot EM-tesen kommer från Kenneth Aizawa och Frederick Adams i boken The bounds of cognition (2010). Den första delen av deras kritik handlar om hur det meningsfulla uppstår. De håller med om att många externa faktorer har betydelse för hur vi gör våra kognitioner, men vi kan bara urskilja deras meningsfullhet genom att värdera det genom hjärnans interna processer. Det handlar då om vilken betydelse representationen av externa faktorer har och man menar att meningsfullhet alltid måste framställas med hjälp av interna egenskaper i hjärnan. Därför kan externa egenskaper inte representera sig själva. Clark framhåller dock att vi faktiskt inte vet vad som är grunden i kognitionen och menar därför att deras kritik har karaktären av att prata mycket om ingenting som vi kan vara säkra på. Han menar att det blir otillfredsställande att bygga kritiken på fördomsfulla uppfattningar om att människan processar allt i hjärnan. Clark framhåller att om den kritiken är rätt så måste man kunna visa hur de interna processerna uppstår (Clark, 2010, p. 1050).

Clark hävdar att det är det externa som kopplar till det interna och på så sätt orsakar externa faktorer många av kognitionerna inom hjärnan. Men Aizawa och Adams (2010) hävdar istället att det helt är genom de interna processerna i hjärnan som kopplingen sker. De hävdar att vi måste skilja på extended cognitive systems och extended cognitive processes. De kan omfatta de senare eftersom bland annat AI-forskaren Rodney Brooks har visat att kognitiva robotar kan komma ganska långt enbart med sådana processer, men då handlar det bara om att klara av att göra uppgifter och inte om att förstå, vilket alltså betyder att de bara fungerar allopoietiskt. De håller också med om det påstående som kopplats till EM-tesen och som säger att den sista utvecklingen till människa skedde genom att vi fick minnessystem. Men de tolkar det inte som ett uttryck för argument som liknar extended mind utan bara som det som hjärnan använder sig av. Här ser vi dock redan att deras försvar faktiskt tvingar ut dem på ett område som vi inte riktigt kan veta något säkert om. Och det förefaller ändå konstigt om inte detta argument skulle visa på att det externa kan påverka hjärnan på ett sätt som inte enbart bestäms av hjärnan..

Det förefaller också som att Clarks positioner stöds av uppfattningar inom modern neurovetenskap. En av de mest intressanta framställningar av hur tekniken påverkar den biologiska organismens kognitiva förmåga är skriven av Miguel Nicolelis, professor i neurologi. Han bygger sina argument på experiment där man har tränat apor att styra robotar genom att använda olika former av redskap. I början handlade det om att de genom att använda styrspakar kunde få en robotarm att hämta frukt. Längre fram opererade man in elektroder i hjärnan så att aporna direkt med sin hjärnverksamhet kunde styra robotarmarna. I det sista experimentet fick man apan att från ett laboratorium i USA styra en robot som fanns i Japan genom sin egen hjärnverksamhet och bara med den observationsförmåga som en dataskärm ger . Dessa experiment handlar just om att testa den representationstes som vi har sett att Aizawa och 
Adams bygger sin argumentation på, samt att pröva vilken betydelse tekniska redskap kan ha för vår kognitiva förmåga. Genom att apan använder tekniska redskap kan man se hur de påverkar dess kapacitet för kognition och genom att det den observerar finns långt bort och förmedlas genom monitorer kan man också se vilken betydelse den omedelbara representationen har.

Nicolelis (2012) går igenom ett antal stadier i neurovetenskapens syn på var i hjärnan den kognitiva förmågan ligger. Han kommer så småningom fram till den uppfattning som tycks vara den som de flesta forskare ansluter sig till och som handlar om att det vi kallar medvetandet är distribuerat på olika håll i hjärnan och att det därför mycket väl kan handla om egenskaper både i kroppen och i den (kulturella) miljö vi befinner oss i.

Det han kallar den relativistiska hjärnhypotesen handlar om att en hjärna som möter nya sätt att ta till sig sin information är mycket villig att ta till sig dessa och genererar på så sätt en ny modell av världen och skapar också en ny bild av hur kroppen ser ut och ser på ett nytt sätt på vilka gränser det finns att definiera individens sätt att uppfatta verkligheten och sig själv (Nicolelis, 2012, p. 243).

Vi kan påpeka att också bland de vygotsky-orienterade pedagogerna kan vi hitta uppfattningar som pekar på att kognitioner kan vara externa. Wertsch har till exempel påpekat att det som man uppfattar som internalisering ofta handlar om sådant som inte sker på ett internt medvetandeplan. Han hävdar att empiriska studier av kognition visar att mycket handlar om processer som aldrig har varit ägnade att internaliseras. Wertsch hänvisar bland annat till studier som har gjorts av Edwin Hutchins där man har undersökt den redskapsanvändning som behövs för att navigera in ett stort fartyg i en hamn. Wertsch menar att Hutchins analys visar på att det som vi uppfattar som internalisering inte är det. Det leder till att Wertsch hellre talar om knowing how och mastery än om internalization (Wertsch, 1998, pp. 50-51).

\section{Kuhlthaus meningssökande paradigm och EM-tesen}

Kuhlthaus meningssökande program inom BoI-vetenskapen kan problematiseras genom att sätta det i relation till de idéer om kontextens och den nya informationsteknologins betydelse som vi har tagit upp.

Kuhlthau (1991) hävdar att det finns sex stadier i informationssökningsprocessen (ISP). Hon menar att modellen innehåller det affektiva, alltså känslor; det kognitiva som här handlar om tankar; samt fysiska handlingar typiska för varje stadium. Hon hävdar också att i modellen är inarbetad de uppgifter som är mest användbara för processerna i de olika stadierna (Kuhlthau, 1991, pp. 366-368). Det första stadiet handlar om den situation då en person först blir medveten om sin brist på kunskap för att förstå ett problem och de känslor av osäkerhet och oro som då är vanliga. De handlingar som hör till detta stadium handlar om att inse ett behov av information och att diskutera olika frågeställningar och angreppssätt. Det andra stadiet handlar om att finna det generella ämnet som skall undersökas. Under detta stadium menar hon att man ofta brukar rådgöra med andra för att väga ämnets perspektiv mot egna intressen och mot vilken information som finns tillgänglig och vilken tid som kan offras. Efter detta stadium brukar ofta osäkerheten bytas ut mot optimism. Det tredje utforskande stadiet kännetecknas av att villrådighet, och då ökar osäkerhet och tvivel. Den tankeverksamhet som är inblandad, handlar då om att undersöka information om det övergripande ämnet i avsikt att utvidga den personliga förståelsen. Vid detta stadium leder en oförmåga att exakt uttrycka vilken information som behövs till att kommunikationen mellan användaren och systemet blir komplicerad. För en del leder detta till en frestelse att helt överge sökningsprocessen. I det fjärde stadiet, som handlar om formulering, uppstår en vändning då osäkerheten förminskas och tilltron till projektet ökar. De handlingar som utförs går ut på att fokusera den information som man har mött i avsikt att formulera ett fokus som liknar en hypotesbildning. I det femte stadiet samlas information in som 
är relaterad till det fokuserade ämnet. Här fungerar också relationen mellan användare och informationssystem som mest effektivt eftersom användaren kan specificera behovet av relevant och fokuserad information till intermediära förmedlare och till systemen.

I det sista stadiet som handlar om presentation, är det vanligt med en känsla av tillfredställelse om sökningen har gått bra eller besvikelse om den har gått dåligt. Handlingar och tankar kretsar kring att använda sökningen till att skapa en personlig syntes av ämnet eller problemet. Handlingarna försöker summera sökningen där minskad relevans och ökad redundans observeras i den information som upptäcks.

Om vi utgår från hur Suchman (2007) resonerar kring villkoren för situerat lärande så kan vi rikta en kritik mot Kuhlthau som handlar om att människan inte på ett rationellt sätt kan leta efter mening. Vi tvingas alltid att pröva oss fram och därför skall vi inte se på osäkerhet i informationssökningsprocessen som något som är patologiskt utan som ett naturligt beteende. Vi kan också påpeka att detta har metodologiska implikationer. Suchman framhåller att det som vi tror var resultat av rationellt tänkande i själva verket var baserat på det som getts av situationerna. Det betyder att det faktiskt är väldigt svårt att genom intervjuundersökningar beskriva informationssökningsbeteenden.

Den viktigaste frågan utifrån vår bibliotekskontext handlar dock om i vilken mån en expert på informationssökning kan hjälpa till i processerna och här är det den tekniska kapacitet som diskuteras i anslutning till Extended Mind tesen som är intressant. Om vi ser på den frågan utifrån det situerade lärandets villkor och de svårigheter att förstå andras intentioner som kontingensfrågan handlar om, bör vi inse att en teknik som låter människorna själva söka sig framåt har uppenbara fördelar. Vi slipper då det moment som består av översättning mellan biblioteksanvändare och bibliotekarie. På så sätt kan användaren fritt utveckla sina reflexioner med hjälp av systemen och kan på så sätt få mycket större frihet i sitt meningssökande. Jag tror vi bör påpeka att Kuhlthaus teori är från tiden för Internets och datateknikens intåg på biblioteken. Vi som har erfarenhet av refererensarbete i informationsdisk vet hur mycket av det arbetet som då utfördes handlade om ganska enkel hjälp med att söka i kataloger, uppslagsböcker och bibliografier. Allt det kan idag användarna själva göra tämligen enkelt med hjälp av datorerna och det har lett till att det mesta av referensarbetet har försvunnit. Visserligen kan alla kunskapssökare ibland behöva hjälp med att ringa in sitt ämne, men då har man sannolikt bättre hjälp av någon som är ämnesexpert än av någon som kan hantera sökredskapens allra mest sofistikerade metoder. Bägge står för de externa faktorer som vi såg att Aizawa och Adams (2010) kritiserade men bibliotekariens externa hjälp är helt instrumentell.

Det går inte att hitta någon text som explicit diskuterar hur Kuhlthaus teori passar ihop med Extended Mind tänkandet. Det finns dock en relativt ny text som försöker argumentera för att Kuhlthaus teori står sig även för de informationssökningsstrategier som görs i dagens miljö där det mesta av litteraturen finns tillgänglig i elektroniskt format och nås via Internet. Problemet är dock att också den texten utgår så mycket från människans rationella förmåga att själv leta sig framåt att den ser på osäkerhet som något som av nödvändighet måste representera ett dysfunktionellt stadium som endast intermediära förmedlare som bibliotekarier kan råda bot på. Man inser inte att osäkerhet faktiskt är enda vägen fram till att hitta något nytt och att den hjälp man kan få av en bibliotekarie sannolikt mest handlar om att hitta det som redan är etablerad kunskap. Man stödjer också argumentationen på intervjuundersökningar vilket jag ovan hävdat är svårt att använda som empiriska belägg. På så sätt skapar man en empiri som inte kan annat än att stödja osäkerheten som något oönskat. På så sätt ser man inte att osäkerhet är ett naturligt beteendet som hellre bör understödjas av en struktur där individen kan pröva sig fram, än av en bibliotekarie som talar om vad som är rätt. I artikeln hänvisas också till ganska gamla texter om det elektroniska tillståndet (Kuhlthau, Heinström, \& Todd, 2008). Vi bör då uppmärksamma att det faktum att litteratur finns elektroniskt publicerat inte i sig tillför så mycket och det är bara den aspekten som referenserna 
i artikeln handlar om. Det som är viktigare är att elektroniska texter gör att de kan nås av effektiva söksystem som inte bara ersätter de mänskliga intermediärernas insatser, utan också skapar en extra dimension till den biblioteksstruktur som alltid på ett mer eller mindre autonomt sätt påverkat kunskapsprocesserna. Det finns en text av en finsk-svensk forskare, Isto Huvila (2011), som argumenterar för att det är avsevärt lättare att hitta information om den skapats för att kunna återvinnas. Han menar i konklusionen till sin artikel att även små förändringar som räknar med de specifika fenomenen med digitala informationsmiljöer, kan ge en signifikant bättre möjlighet att hitta information. Därför menar han att informationskompetens begreppet också skall innefatta den stora vidd kvaliteter och förväntningar som finns i själva informationsobjekten (Huvila, 2011).

\section{Slutsatser}

Vi har visat att det finns starka argument för att det är viktigare att satsa på elektroniska bibliotek som använder modern teknik för att bygga en bra biblioteksstruktur och som använder sig av datatekniska informationsredskap än att satsa på bemannade skolbibliotek eller andra bemannade små bibliotek knutna till läroinstitutioner. Det behövs bibliotekarier som kan bygga dessa strukturer och ta initiativ till att använda den moderna informationstekniken, men dessa behöver inte vara verksamma som intermediära förmedlare. Det betyder att det finns goda möjligheter att ersätta de små skolbiblioteken med centraliserade elektroniska bibliotek. 


\section{Referenser}

Adams, F. \& Aizawa, K. (2010). The bounds of cognition. Oxford: Wiley-Blackwell.

Bateson, G. (1973). Steps to an ecology of mind: collected essays in anthropology, psychiatry, evolution and epistemology. London: Granada.

Baecker, Dirk (2008) The network Synthesis of Social Action II: Understanding Catjects. Cybernetics and Human Knowing, 15(1), 45-66.

Borkum, E., He, F., Linden, L.L. (2013). The Effects of School Libraries on Language Skills: Evidence from a Randomized Controlled Trial in India. Retrieved from http://ftp.iza.org/dp7267.pdf

Clark, A. (2010). Much Ado About Cognition. Mind, 119(476), 1047-1066.

Clark, A. (2003). Natural-born cyborgs: Minds, technologies, and the future of human intelligence. Oxord: Oxford University Press.

Clark, A., Chalmers D. (1998) The extended mind. Analysis, 58, 7-19.

Dolatkhah, M. et.al. (2013). Skolbiblioteken allt annat än meningslösa. Dagens Nyheter, 2013-1004.

Engeström, Y. (1987). Learning by Expanding: An Activity Theoretical Approach to Developmental Work Research. Helsinki: Orienta.

Grant, C. B. (2003). Destabilizing Social Communication Theory. Theory, Culture \& Society, 20(6), 95-119.

Hayles, N. K. (1999). How We Became Posthuman: Virtual Bodies in Cybernetics, Literature, and Informatics. Chicago: University of Chicago Press

Huvila, I. (2011). The complete information literacy? Unforgetting creation and organization of information. Journal of Librarianship and Information Science, 43(4), 237-245.

Kuhlthau, Carol C. (1991). Inside the Search Process: Information Seeking from the User's Perspective. Journal of the American Society for Information Science, June, 366-368.

Kuhlthau, C.C., Heinström, J. \& Todd, R.J. (2008). The information search process revisited: is the model still useful?. Information Research, 13(4). Retrieved from http://www.informationr.net/ir/13-4/paper355.html.

Liberg, C. \& Houltzén, E. (2013). Räcker inte att prata om bibliotekariers närvaro. Dagens Nyheter, 2013-10-09.

Loertscher, D. V. (2000). Taxonomies of the school library media program, 2. ed. San José: Hi Willow.

Luhmann, N. (1971). Sinn als Grundbegriff der Soziologie. In N. Luhmann \& J. Habermas (Eds.) Theorie der Gesellschaft oder Sozialtechnologie Was leistet die Systemforschung? (pp. 25100). Frankfurt am Main: Suhrkamp. 
Nicolelis, M. (2012). Beyond boundaries : the new neuroscience of connecting brains with machines-and how it will change our lives. New York: St. Martin's Press.

Sahlgren, G. H. (2013). Stryk kravet på skolbibliotek helt. Dagens Nyheter, 2013-10-01.

Suchman, L. A. (2007). Human-machine reconfigurations: plans and situated actions, 2nd ed. Cambridge: Cambridge University Press

Stables, A. (2005). Living and learning as semiotic engagement : a new theory of education. Lewiston: Edwin Mellen Press.

Wertsch, J. W. (1985). Vygotsky and the Social Formation of Mind. Cambridge, Mass.: Harvard University Press.

Wertsch, J. W. (1998). Mind as Action. Oxford: Oxford University Press

Wheeler, M. (2010). In Defence of Extended Functionalism. In R. Menary (Ed.) Extended Mind (pp. 245-270). Cambridge, Mass.: MIT Press. 